University of Nebraska - Lincoln

DigitalCommons@University of Nebraska - Lincoln

USDA National Wildlife Research Center - Staff Publications
U.S. Department of Agriculture: Animal and Plant Health Inspection Service

2013

\title{
Wildlife strikes to civil helicopters in the US, 1990-2011
}

Brian E. Washburn

United States Department of Agriculture, brian.e.washburn@aphis.usda.gov

Paul Cisar

Aberdeen Proving Grounds

Travis L. DeVault

USDA/APHIS/WS National Wildlife Research Center, Travis.L.DeVault@aphis.usda.gov

Follow this and additional works at: https://digitalcommons.unl.edu/icwdm_usdanwrc

Washburn, Brian E.; Cisar, Paul; and DeVault, Travis L., "Wildlife strikes to civil helicopters in the US, 1990-2011" (2013). USDA National Wildlife Research Center - Staff Publications. 1247.

https://digitalcommons.unl.edu/icwdm_usdanwrc/1247

This Article is brought to you for free and open access by the U.S. Department of Agriculture: Animal and Plant Health Inspection Service at DigitalCommons@University of Nebraska - Lincoln. It has been accepted for inclusion in USDA National Wildlife Research Center - Staff Publications by an authorized administrator of DigitalCommons@University of Nebraska - Lincoln. 


\title{
Wildlife strikes to civil helicopters in the US, 1990-2011
}

\author{
Brian E. Washburn ${ }^{\mathrm{a}, *}$, Paul J. Cisar ${ }^{\mathrm{b}}$, Travis L. DeVault ${ }^{\mathrm{a}}$ \\ ${ }^{a}$ US Department of Agriculture, Animal Plant Health Inspection Service, Wildlife Services, National Wildlife Research Center, 6100 Columbus Avenue, Sandusky, \\ $\mathrm{OH} 44870$, USA \\ ${ }^{\mathrm{b}}$ US Army, Logistics Division, Aberdeen Test Center, Aberdeen Proving Grounds, MD 25001, USA
}

\section{A R T I C L E I N F O}

\section{Keywords:}

Airfields

Aviation accidents

Helicopter

Wildlife strikes

\begin{abstract}
A B S T R A C T
This paper examines wildlife strikes with civil helicopters within the US. Month and time of day, location, and other factors influenced the frequency of wildlife strikes with civil helicopters. Wildlife strikes occurred most frequently when the aircraft were traveling en route or engaged in terrain flight. Birds accounted for over $97 \%$ of the wildlife strikes where the animal was identified.
\end{abstract}

Published by Elsevier Ltd.

\section{Introduction}

The general aviation industry provides important contributions to the US economy and civil helicopters are an important component of the US general aviation aircraft fleet. In 2010, more than 10,100 civil helicopters completed over 3,405,000 flight hours within the US (General Aviation Manufacturers Association, 2013). Wildlife-aircraft collisions (wildlife strikes) with civil and military aircraft, however, pose a serious hazard to aircraft, and annually cost civil aviation more than $\$ 718$ million in the US and an estimated \$1.2 billion worldwide (Dolbeer et al., 2012). Wildlife strikes have resulted in the loss of more than 276 lives and more than 200 military and civil aircraft since 1988 . Recent wildlife strike events, such as the ditching of US Airways Flight 1549 into the Hudson River, have drawn the attention of local and national media and increased public interest in risks to aviation safety posed by wildlife.

The Federal Aviation Administration (FAA) maintains the FAA National Wildlife Strike Database (NWSD) for civil aviation in the US and produces annual summary reports. Although several examinations of wildlife strikes with fixed wing aircraft (both civilian and military) have been conducted (e.g. Dolbeer et al., 2000; Zakrajsek and Bissonette, 2005; DeVault et al., 2011), there are currently no comprehensive analyses of wildlife strike hazards for civil helicopters. In 2006, the US Department of Agriculture and the FAA conducted a cursory investigation into reported bird strikes to civil helicopters during 1990-2005 (Cleary et al., 2006). This analysis indicated that patterns of reported bird strikes to civil helicopters were very different from those involving civil fixed wing aircraft. These differences in patterns of bird strikes among aircraft types warrant further study. The objective of this project is to conduct a comprehensive analysis of data available from wildlife strikes with civil helicopters within the US during from 1990 to 2011.

\section{Methodology}

Wildlife strike data for civil helicopters within the US are available from the NWSD and acquired through a voluntary reporting system and information that is primarily provided by pilots and airports (Dolbeer et al., 2012). We obtained wildlife strike records from 1990 to 2011 and parsed our database to include only strikes to civil helicopters that were reported to

\footnotetext{
* Corresponding author. Tel.: +1 4196250242.

E-mail address: brian.e.washburn@aphis.usda.gov (B.E. Washburn).
} 
have occurred within the contiguous US, Alaska, Hawaii, or near shore areas within 16 miles of the coast. Many strike reports were incomplete and specific fields of information were missing or unknown; thus sample sizes varied among variables and specific analyses.

We determined the time of day each wildlife strike event occurred based on the reported local time of the event. Strike events occurring between 08:00 to 18:00 local time were categorized as 'day', whereas strikes between 20:00-06:00 were categorized as 'night'. 'Dawn' strike events occurred during 06:00-08:00 and 'dusk' during 18:00-20:00.

Phase of flight was defined as the phase of flight the helicopter was in at the time the wildlife strike occurred (Federal Aviation Administration, 2000; US Army, 2012). Helicopters in the 'en route' phase of flight are flying at or higher than $305 \mathrm{~m}$ above ground level (AGL), whereas helicopters in 'terrain flight' are below $305 \mathrm{~m}$ AGL. 'Hovering' helicopters are off the ground, but below 305 m AGL, and stationary. Helicopters on 'approach' are in early stages of the landing process at or above $30.5 \mathrm{~m} \mathrm{AGL}$, and moving forward typically on or over an airfield. 'Landing' helicopters are in the final stages of landing and less than $30.5 \mathrm{~m}$ AGL. 'Taxiing' helicopters are moving along the ground or less than $3.1 \mathrm{~m}$ AGL in a transition from one part of the airfield to another, e.g. moving from a hanger to an active helipad. Helicopters in the 'take-off' phase are in the process of leaving the ground ascending upward at, or below $30.5 \mathrm{~m}$ AGL. Helicopters in the 'climb out' phase are in the later stages of 'taking off' above $30.5 \mathrm{~m} \mathrm{AGL}$ and moving forward, typically on or over the airfield.

A wildlife strike event with a civil helicopter is defined as a damaging strike if there is any amount of damage to the aircraft. Damaging wildlife strikes vary greatly in the amount of damage incurred to the aircraft, ranging from minor abrasions found on the airframe or an aircraft component to the complete destruction of the aircraft.

Previous studies of fixed wing aircraft show differences in the patterns of bird strikes occurring within the airport environment and those that occur while aircraft are traveling away from an airfield (Dolbeer, 2011). For each wildlife strike, the location of the strike event, if known, is determined to be 'on-airfield' if the helicopter was within the horizontal delineation of an airfield when it occurred. 'Off-airfield' strikes are defined as wildlife strikes that occur when an helicopter is not 'on' or flying over an airfield.

For each wildlife strike event, if information was available, the animals involved was assigned to one of 23 wildlife groups. Wildlife groups were based on guilds and taxonomic groupings of related wildlife species and families (DeGraff et al., 1985). In cases where the wildlife involved was identified to the species level, we assigned that wildlife strike to the appropriate wildlife group based on the species involved [e.g. Canada geese (Branta canadensis) were be assigned to the 'Waterfowl' wildlife group]. Wildlife strike events to civil helicopters involving more than one animal - e.g. a flock of birds - were treated the same as a strike event that involved only one animal because the number of individuals involved was not available for most strike reports.

We obtained flight information - i.e., number of flight hours - for 1990-2011 for civil helicopters within the US from the Federal Aviation Administration. We summarized these data and determined the number of flight hours each year and also calculated the proportion of civil helicopter flight hours for day and night time periods. Our investigation included identification of trends in wildlife strikes with civil helicopters with respect to a variety of factors. We summarized wildlife strikes that occurred within airport environments separately from those that occurred during 'off-airfield' flight operations. We used $t$-tests to determine if significant differences occurred in the number of reported wildlife strikes to civil helicopters among years. We used chi-squared analysis to compare the number of wildlife strikes with civil helicopters by month and time of day. Descriptive statistics were used to quantify the frequency of wildlife strikes that occurred among the aircraft phases of flight and the estimated financial costs of wildlife strikes.

\section{Results}

\subsection{Temporal patterns in wildlife strikes}

We found 1044 wildlife strikes with civil helicopters among the records of the NWSD that occurred within the US during 1990-2011. These helicopters were from a variety of public and private organizations, including US federal government agencies (e.g. US Department of Homeland Security), private companies (e.g. Rocky Mountain Helicopters), medical and emergency services, and private citizens.

In the years prior to the US Airways 1549 incident, an average of 27.9 reported wildlife strikes to civil helicopters occurred annually (Fig. 1). The average number of wildlife strikes in the first 3 years following the US Airways 1549 incident was over six times higher than during the previous 19 years. During 1990-2011, civil helicopters conducted an average of 2,511,227 $( \pm 122,922$ SE) flight hours annually in the US (Fig. 1). In contrast to the number of reported wildlife strikes, there was not an increase in flight hours by civil helicopters during 2009-2011. The number of reported strikes varied among months, the highest numbers of strikes occurring in September and October whereas the lowest number was found December and January (Fig. 2).

The proportion of strikes to helicopters varied among times of day. Although approximately $81.3 \%$ of the helicopter flight hours occurred during the day, approximately half (51.3\%) of the reported wildlife strikes occurred during the day. Notably, $43.7 \%$ of reported wildlife strikes occurred at night even though only $18.7 \%$ of the flight hours for helicopters occurred during night time hours. Approximately $5 \%$ of the strikes occurred during dawn and dusk. 


\subsection{Geographic locations and aircraft phase of flight}

Among the 930 wildlife strikes with civil helicopters for which the specific geographic location (i.e., state) where the incident occurred was determined, the majority occurred in Louisiana (12.2\%), Texas (10.1\%), California (9.0\%), Arizona (7.1\%), and Florida (6.8\%). Wildlife strikes to civil helicopters occurred in all US states and the District of Columbia, except Rhode Island.

Wildlife strikes to civil helicopters occurred during all (aircraft) phases of flight. When the phase of flight was reported, strikes occurred most frequently when helicopters were traveling en route (Table 1). Overall, the proportion of wildlife strikes that occurred when the aircraft was en route or in terrain flight (combined phases) of flight was 65\%.

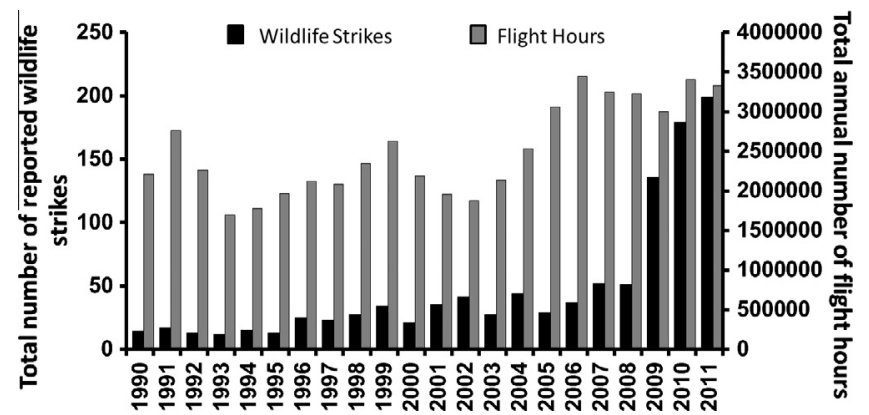

Fig. 1. Annual number of reported wildlife strikes with civil helicopters and of flight hours for civil helicopters (1990-2011).

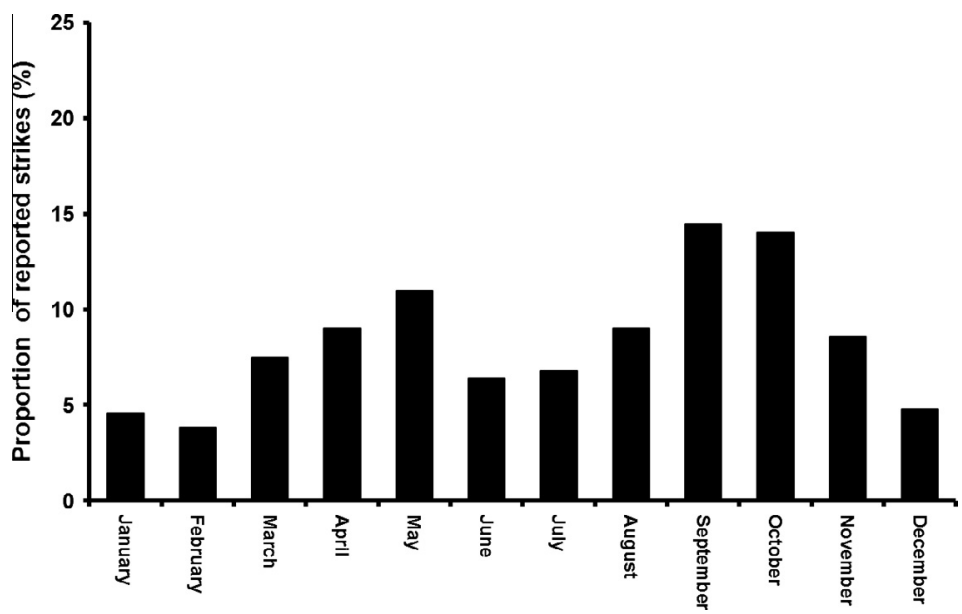

Fig. 2. Monthly percentage of reported wildlife strikes with civil helicopters (1990-2011).

Table 1

Percentage of reported wildlife strikes with civil helicopters by phase of flight (1990-2011).

\begin{tabular}{lc}
\hline Phase of flight & \% of strikes \\
\hline En route & 53.1 \\
Terrain flight & 11.9 \\
Hovering & 0.7 \\
Approach & 18.2 \\
Landing & 0.5 \\
Taxiing & 2.6 \\
Take-off & 0.8 \\
Climb out & 12.2 \\
\hline
\end{tabular}




\subsection{Groups/species of wildlife involved}

Among the strike records, $37.2 \%$ and $16.0 \%$ identified the animal struck to the 'wildlife group' and species level. Seventyfive species of wildlife were reported among the civil helicopter strikes. Birds accounted for $97.2 \%$ of the wildlife strikes, whereas bats and large mammals accounted for the remaining $2.8 \%$. Gulls, waterfowl, and raptors and vultures were the wildlife groups most frequently struck, accounting for $26.8 \%, 19.8 \%$, and $19.6 \%$ of all strikes with helicopters. Eleven mammal strikes were reported, including two with Brazilian free-tailed bats (Tadarida brasiliensis), four with bats of 'unidentified' species, two with cattle (Bos taurus), and one each with a coyote (Canis latrans), a moose (Alces alces), and a white-tailed deer (Odocoileus virginianus).

\subsection{Aircraft damages/losses}

The proportion of all reported wildlife strikes that were damaging to helicopters was $36.3 \%$. The proportion of strikes that damaged helicopters was five times higher for off-airfield strike events (40\%) than for on-airfield strikes (Table 2). The average cost of a damaging wildlife strike [i.e., estimate of damaged parts and repair costs] was $\$ 41,158$ per incident. Collisions between wildlife and civil helicopters operating in the US resulted in 52 human injuries and nine fatalities during 19902011. The injuries occurred during 47 wildlife strike incidents. Most human injuries consisted of cuts, lacerations, and/or bruising to pilots and copilots when birds impacted the windscreen of the aircraft, shattering the windscreen of the aircraft and sending glass and bird remains into the aircraft cabin. Most human fatalities occurred when a red-tailed hawk collided with a private helicopter in Louisiana during 2009. Eight people died in this strike event, which also resulted in the destruction of the aircraft when it crashed.

\subsection{On-airfield wildlife strikes}

Among the wildlife strikes reported to have occurred on or over airfields (i.e., on-airfield), 53.3\% contained information regarding the identity of the animal struck. Birds accounted for $98.3 \%$ of the on-airfield strikes. Gulls, doves and pigeons [e.g. rock pigeons (Columba livia)], herons, egrets and ibises, and waterfowl were the wildlife groups most frequently struck by helicopters (Table 3). Four on-airfield mammal strikes were reported, including one each with a bat of 'unidentified' species, a cow, a coyote, and a white-tailed deer.

When only on-airfield damaging strikes are considered, $70 \%$ contained information regarding the identity of the animal struck. Waterfowl (i.e., mallard), a gull (species unknown), a killdeer (Charadrius vociferus), a great-horned owl (Bubo virginianus), and a cattle egret (Bubulcus ibis) were involved in strikes that resulted in damage to helicopters operating on-airfield (Table 3). One on-airfield damaging strike event with a mammal was reported; this strike involved a cow and the helicopter was completely destroyed by the resulting crash. The average cost of an on-airfield damaging wildlife strike was $\$ 378,539$ per incident. There was one reported human injury and no reported fatalities due to a wildlife strike to a civil helicopter during on-airfield flight operations. A pilot received cuts and lacerations when a bird impacted the windscreen of the aircraft.

\subsection{Off-airfield wildlife strikes}

Among the wildlife strikes that occurred away from airfields, $36.6 \%$ contained information regarding the identity of the animal struck. Birds accounted for $98.4 \%$ of on-airfield strikes. Gulls, raptors and vultures, and waterfowl were the wildlife groups most frequently struck by civil helicopters (Table 3). Five off-airfield mammal strikes to helicopterswere reported, including one with Brazilian free-tailed bat (Tadarida brasiliensis), two with bats of 'unidentified' species, one with a cow, and one with a moose. When only off-airfield damaging strikes are considered, $68.5 \%$ contained wildlife identify information. Raptors and vultures (e.g. red-tailed hawks and turkey vultures), waterfowl (e.g. Canada geese and mallards), and gulls [e.g. herring gulls (Larus argentatus) and ring-billed gulls (Larus delawarensis)] were most frequently involved in off-airfield damaging strikes (Table 3). Two off-airfield damaging mammal strikes were reported, one each with a cow and a moose.

Table 2

Reported wildlife strikes with civil helicopters, without or with aircraft damage, where the strike occurred 'on-airfield' and 'offairfield' (1990-2011).

\begin{tabular}{lc}
\hline Location & Number of strikes \\
\hline On-airfield & \\
Non-damaging & 110 \\
Damaging & 10 \\
Off-airfield & \\
Non-damaging & 514 \\
Damaging & 345 \\
\hline
\end{tabular}


Table 3

Wildlife strikes and damaging wildlife strikes with civil helicopters where the aircraft was reported as being 'on-airfield' and 'off-airfield' (1990-2011).

\begin{tabular}{|c|c|c|c|c|}
\hline \multirow[t]{2}{*}{ Species group } & \multicolumn{2}{|l|}{ On-airfield } & \multicolumn{2}{|l|}{ Off-airfield } \\
\hline & All strikes & Damaging strikes & All strikes & Damaging strikes \\
\hline Bats $^{\mathrm{a}}$ & $1^{\mathrm{a}}$ & & $3^{\mathrm{c}}$ & \\
\hline Blackbirds and starlings & 2 & & 9 & 5 \\
\hline Corvids & & & 3 & 2 \\
\hline Cuckoos & & & 1 & \\
\hline Doves and pigeons & 9 & & 11 & 7 \\
\hline Finches & 2 & & 1 & \\
\hline Gulls & 27 & 1 & 75 & 49 \\
\hline Herons, egrets, and ibises & 5 & 1 & 7 & 3 \\
\hline Large mammals & $3^{\mathrm{b}}$ & 1 & $2^{d}$ & 2 \\
\hline Nightjars & 1 & & & \\
\hline Owls & 1 & 1 & 1 & 1 \\
\hline Perching birds & & & 1 & \\
\hline Raptors and vultures & 2 & & 71 & 59 \\
\hline Seabirds & & & 3 & 2 \\
\hline Shorebirds & 3 & 1 & 5 & 3 \\
\hline Sparrows & 2 & & 12 & 2 \\
\hline Swallows & 1 & & 3 & 1 \\
\hline Thrashers and thrushes & & & 1 & 1 \\
\hline Tropicbirds & & & 11 & 7 \\
\hline Vireos & & & 2 & \\
\hline Warblers & & & 4 & \\
\hline Waterbirds & 5 & 2 & 17 & 14 \\
\hline Waterfowl & & & 71 & 55 \\
\hline Unidentified spp. & 56 & 3 & 545 & 132 \\
\hline
\end{tabular}

${ }^{a}$ Comprised of Brazilian free-tailed bats (Tadarida brasiliensis), Eastern pipistrelles (Perimyotis subflavus), evening bats (Nycticeius humeralis), hoary bats (Lasiurus cinereus), red bats (L. borealis), Seminole bats (L. seminolis), silver-haired bats (Lasionycteris noctivagans), and 'unidentified' species.

b Large mammals was comprised of cow (Bos taurus), coyote (Canis latrans), and white-tailed deer (Odocoileus virginianus).

c Comprised of big brown bats (Eptesicus fuscus), Brazilian free-tailed bats, Eastern pipistrelles, hairy-tailed bats (Lasiurus ebenus), hoary bats, pocketed free-tailed bats (Nyctinomops femorosaccus), red bats, Seminole bats, silver-haired bats, Western pipistrelles (Pipistrellus hesperus), and'unidentified' species.

${ }^{\mathrm{d}}$ Large mammals was comprised of a cow and a moose (Alces alces).

The average cost of an off-airfield damaging wildlife strike was $\$ 32,338$ per incident. There were 50 reported human injuries and nine fatalities due to wildlife strikes to civil helicopters conducting flight operations off-airfield. Two wildlife strike incidents resulted in the loss of nine people; one involved a red-tailed hawk and one involved an unknown species of wildlife.

\section{Conclusions}

Since 2009, there has been a sixfold increase in the US in the annual number of reported wildlife strikes with civil helicopters. This increase in wildlife strike reports to the NWSD is likely the result of increased awareness following the ditching of US Airways Flight 1549 in the Hudson River in 2009, and the fatal crash of a privately owned helicopter in Louisiana in the same year. Temporal patterns of wildlife strikes to civil helicopters are evident, and consistent with strikes to fixed wing aircraft, these events occur with the greatest frequency during the fall migration of birds. A disproportionate number of wildlife strikes with helicopters also occurs at night.

Almost half of reported strikes to helicopters occurred while the aircraft was in the en route phase of flight, whereas onethird of wildlife strikes to civil helicopters occurred during the climb out phase of flight. This is in contrast to wildlife strikes to civilian fixed wing aircraft, where the frequency of those strikes is typically lowest during the en route phase of flight (Dolbeer et al., 2012). However, fixed wing aircraft (both private and commercial) flying en route to a destination would typically be at a much higher altitude than helicopters and above the airspace typically used by birds and bats (Washburn and Olexa, 2011). The high frequency of reported strikes during climb out suggests that managing wildlife hazards within airfield environments might be effective in reducing the risk of wildlife-helicopter collisions on or near airports and heliports.

Gulls, raptors and vultures (e.g. red-tailed hawks and turkey vultures), and waterfowl (e.g. Canada geese and mallards) were the wildlife groups that collided with helicopters most often. Similarly, these were the same wildlife groups, and species of birds, that caused damage to helicopters during off-airfield flight operations. On-airfield wildlife strikes were much less common, but raptors and vultures, waterfowl, and shorebirds struck and damaged civil helicopters within airport environments. Although collisions between large mammals and helicopters were rare, when these incidents did occur significant damage to the aircraft, and often the complete loss of the helicopter, was the result. Although on-airfield wildlife strikes represents a serious safety issue, strikes to helicopters during off-airfield flight operations accounted for a greater frequency of damaging strikes. Further, the majority of human injuries and fatalities occurred during off-airport flight operations. 


\section{Acknowledgments}

We thank the US Department of Defense Legacy Resource Management Program for funding this project. We appreciate the encouragement, professional advice, and data access provided by the FAA. B. Blackwell, T. Seamans, and an anonymous reviewer provided helpful comments on earlier drafts of the manuscript. This manuscript reflects the views of the National Wildlife Research Center and does not necessarily reflect the views of the DoD Legacy Resource Management Program or the FAA.

\section{References}

Cleary, E.C., Dolbeer, R.A., Wright, S.E., 2006. Wildlife Strikes to Civil Aircraft in the United States 1990-2005. US Department of Transportation, Federal Aviation Administration National Wildlife Strike Database, Serial Report Number 12. Washington, DC.

DeGraff, R.M., Tilghman, N.G., Anderson, S.H., 1985. Foraging guilds of North American birds. Environmental Management 9, $493-536$.

DeVault, T.L., Belant, J.L., Blackwell, B.F., Seamans, T.W., 2011. Interspecific variation in wildlife hazards to aircraft: implications for airport wildlife management. Wildlife Society Bulletin 35, 394-402.

Dolbeer, R.A., 2011. Increasing trend of damaging bird strikes with aircraft outside the airport boundary: implications for mitigation measures. HumanWildlife Interactions 5, 235-248.

Dolbeer, R.A., Wright, S.E., Cleary, E.C., 2000. Ranking the hazard level of wildlife species to aviation. Wildlife Society Bulletin 28, 372-378.

Dolbeer, R.A., Wright, S.E., Weller, J., Begier, M.J., 2012. Wildlife Strikes to Civil Aircraft in the United States 1990-2011. FAA National Wildlife Strike Database, Serial Report Number 18. Washington, DC.

Federal Aviation Administration, 2000. Rotorcraft Flying Handbook. US Department of Transportation, FAA, Flight Standards Service, FAA-H-8083-21, Washington, DC.

General Aviation Manufacturers Association, 2013. 2012 General Aviation Statistical Databook and Industry Outlook. GAMA, Washington, DC.

Washburn, B.E., Olexa, T.J., 2011. Assessing BASH Risk Potential of Migrating and Breeding Osprey in the Mid-Atlantic Chesapeake Bay Region. Final Report to the US Department of Defense, Legacy Resources Management Program, Arlington.

US Army, 2012. Fundamentals of Flight (FM 3-04.203). Independent Publishers Group, Chicago.

Zakrajsek, E.J., Bissonette, J.A., 2005. Ranking the risk of wildlife species hazardous to military aircraft. Wildlife Society Bulletin 33, $258-264$. 